\title{
Predictability of Northeast Monsoon Rainfall over Southern India using Global Pressure Oscillations
}

\author{
S. R. Rao*
}

Department of Meteorology \& Oceanography, Andhra University, Visakhapatnam - 530 003, India

\begin{abstract}
Main focus of this hind cast study is to develop an algorithm for predicting northeast monsoon rainfall (NEMR) using global atmospheric pressure oscillations over south India. Analysis of 129-years datasets indicates that the Southern Oscillation Index (SOI) of April and May (AM) is inversely related (-0.56) with NEMR during 1959 to 2004; similarly the North Atlantic Oscillation (NAO) of January and February (JF) also exhibits similar relationship (-0.36) with predictant for the above study period. Simple linear equations are developed with above predictors to predict rainfall and they are tested for the succeeding six years, 1999-2004. To further confirm the consistency of above relationships, 20-year sliding window test is performed which is statistically significant. Secondly for extreme cases of rainfall events MannWhitney rank statistical test is performed and it repeats the same relationship. Above two predictors are statistically independent of each other and a multiple correlation coefficient (MCC) among two predictors and predictant is 0.66 for the common period 1959-1998, which is significant at the $0.1 \%$ level. Above MCC suggests a multiple regression equation for predicting NEMR, which is tested for succeeding six years (1999-2004). Leave-One-Out (L-O-O) cross validation test is applied for the estimated rainfall (significant at the 5\% level), while root mean square error is $89.8 \mathrm{~mm}$. Finally, observational evidence for variations of Hadley circulation, which is integral portion of northeast monsoon region is provided using NCEP/NCAR reanalysis data sets for the period 1959-2004 and the circulation features are very contrasting in extreme years of atmospheric oscillations.
\end{abstract}

Keywords: Northeast monsoon, North Atlantic Oscillation, Southern Oscillation Index.

\section{INTRODUCTION}

Whereas Indian summer monsoon, a principal rainy season has been the main focus on long-range prediction since the time of [1], the NEMR is defined by the India Meteorological Department as rainfall during October through December, which is crucial for the Rabi crop over south India. Northeast monsoon is also called as winter/ retreating southwest monsoon and during this season, the semi-permanent systems of summer monsoon over India and neighbourhood namely the Mascerene high, the Somali jet, the Tibetan anticyclone, the easterly jet stream over south India and the monsoon trough along the Ganges valley etc are replaced gradually by the Siberian anticyclone, cold surges from Siberian high, the western Pacific high, a subtropical westerly jet stream over north India and monsoon trough over Indonesia [2]. As south India is sheltered by the Western Ghats, summer monsoon rains are not much due to rain-shadow-effect. On the other hand northeast monsoon provides up to $60 \%$ of yearly total rainfall over south India in general and Tamilnadu in particular. For example Vedaranyam $\left(10^{\circ} 25^{\prime} \mathrm{N} ; 79^{\circ} 35^{\prime} \mathrm{E}\right)$, located in the central coastal Tamilnadu receives a normal rainfall of $1027.7 \mathrm{~mm}$, which is by far the highest of any station in India during the northeast monsoon season. However, evaluation of seasonal prediction of rainfall over south India has received a limited attention so far.

*Address correspondence to this author at the Department of Meteorology \& Oceanography, Andhra University,Visakhapatnam - 530 003, India;

Tel: 91-891-2844639; Fax: 91-891-2626111; E-mail: raos59@ gmail.com
First [3] defined the term northeast monsoon and later [4] addressed the importance of northeast monsoon rainfall for agriculture of south India. By and large NEMR is connected with westward moment of tropical cyclones, depressions, north-south trough activity, coastal convergence and disturbances in equatorial troughs and easterly waves [5] from the Pacific. Though the impact of 30-60 day oscillation is considerably high on the Indian summer monsoon, it does not have much role on NEMR [6]. The main characteristic of NEMR is that it results from a small number of events occurring during two or three week period of the northeast monsoon season over south India even during the years of normal/above normal rainfall and adequate steps have to be taken for storing such occasional high amounts of rainfall for power production and agricultural activity and interestingly NEMR is more crucial when the Indian summer monsoon fails. There are several studies, which have examined the relation between SOI and Indian summer monsoon rainfall [7-13] and it is observed that the relation between them has been weaking in the last two decades [14], while studies of the influence of SOI on NEMR are meager. Recent research work supports the contention that SOI is negatively correlated with NEMR over south India, but no algorithm is developed for long-range prediction of NEMR over south India, except a few studies by [15-22]. Secondly, the NAO is one of the most prominent and recurrent patterns of atmospheric circulation variability, which exerts a profound influence on northeast monsoon circulation during the cold season. Agricultural harvests, water management, energy 
supply and demand, and yields from fisheries, among many other things are correlated with the NAO. Several recent studies have concluded that NAO variability is closely tied to sea surface temperature variations over the tropical north and south Atlantic [23-27]. The IMD used NAO as one of predictors for long-range prediction of summer monsoon rainfall in the year 2007, but no attempt is made to examine the relationship between NAO and NEMR. The author so made an attempt to formulate an algorithm for the assessment of NEMR using monthly indices of Southern Oscillation ( $\mathrm{SO}$ ) and NAO in the present study as there are no such studies in this direction so far.

\section{DATA AND METHODS}

South India comprises of five meteorological subdivisions namely coastal Andhra Pradesh (CAP), Rayalaseema, Tamilnadu, south interior Karnataka (SIK) and Kerala (Fig. 1); this study will utilize five important datasets: mean monthly NEMR over south India from www.tropmet. res.in and SOI for different months (http://www.bom.gov.au) for the period 1876-2004 and NAO is obtained from the NOAA website http://www.cpc.ncep.noaa.gov, NCEP/NCAR reanalysis data (http://www.cdc.noaa.gov) and Indian daily weather reports (IDWRs) for frequency of tropical cyclones over the Bay of Bengal during extreme cases of NEMR for the period 1959-2004. The area-weighted NEMR is determined from the above individual sub-divisional rainfall amounts by considering their areas as weights for the period 1959-2004. In the present hind cast study the intercorrelations between seasonal rainfall of five meteorological subdivisions are positive and statistically significant ( $1 \%$ level) and hence that the rainfall over different meteorological subdivisions varies in the same sense. Thus the study region is considered to be coherent. Hence this series can be treated as a measure of the intensity of NEMR over south India; it is noticed that of all the five sub-divisions, except Tamilnadu and SIK sub-divisionals rainfall show significant increasing trend (Fig. 2). The SOI is defined as the record of the monthly or seasonal fluctuations in the normalized surface air pressure difference between Darwin, Australia $\left(12^{\circ} \mathrm{S}, 131^{\circ} \mathrm{E}\right)$ and Tahiti $\left(18^{\circ} \mathrm{S}, 149^{\circ} \mathrm{W}\right)$. Next, the NAO index is defined as the pressure difference between various stations to the north (Iceland $-63^{\circ} \mathrm{N}, 30^{\circ} \mathrm{W}$ ) and south (Azores- $40^{\circ} \mathrm{N}, 30^{\circ} \mathrm{W}$ ) of the middle latitude westerly flow. Finally, to establish probable observational evidence for the empirical relationships between atmospheric oscillations and NEMR, the NCEP/NCAR reanalysis datasets [28] are used to study circulation changes in terms of horizontal and vertical extent and intensity of Hadley cell in contrasting years for extreme negative and positive cases of atmospheric oscillations. Simple, multiple correlations and regression techniques, 20-year sliding window and



Fig. (1). Meteorological sub-divisions affected by northeast monsoon over south India (shaded area): coastal Andhra Pradesh (27), Rayalaseema (29), Tamilnadu (30), south interior Karnataka (33) and Kearala (34). 


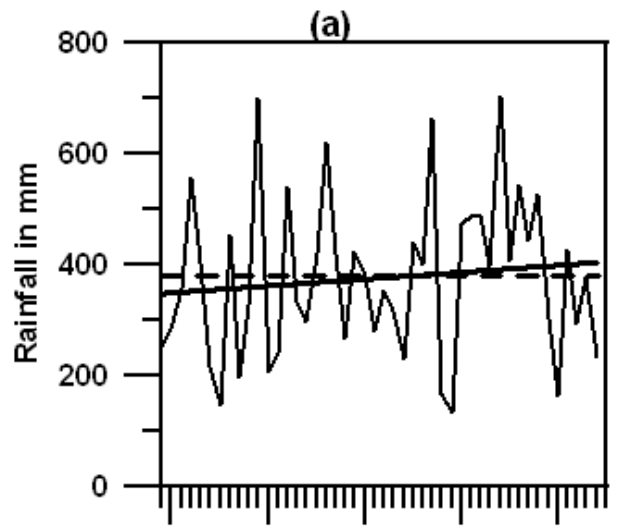

(c)

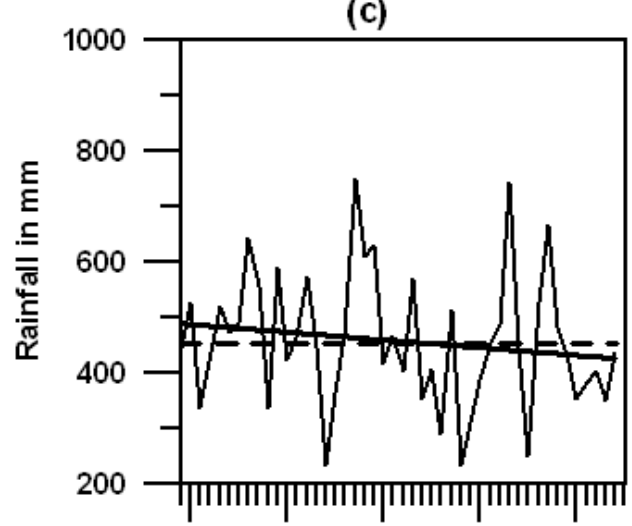

(e)



(b)

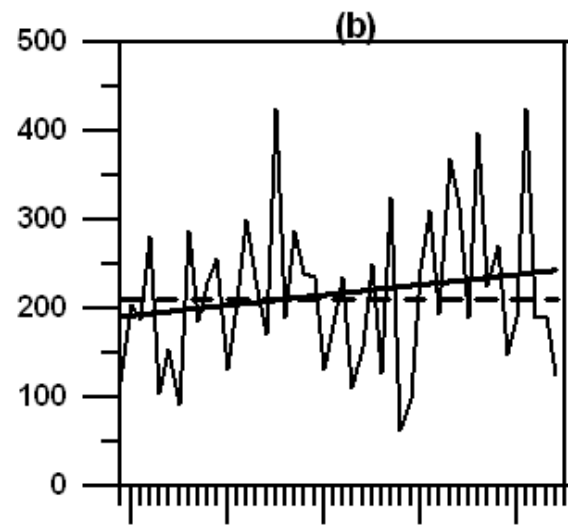

(d)

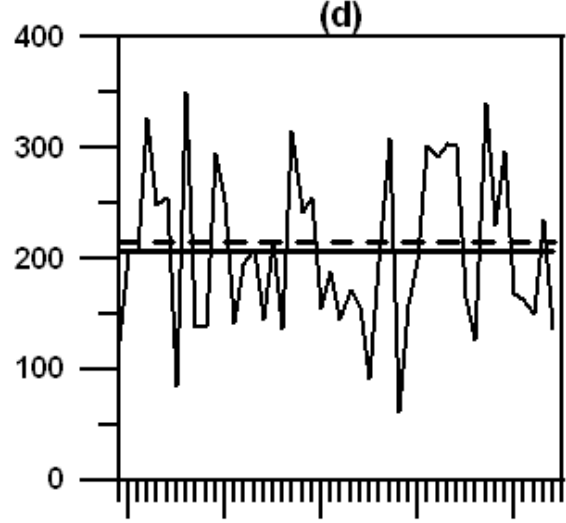

(f)

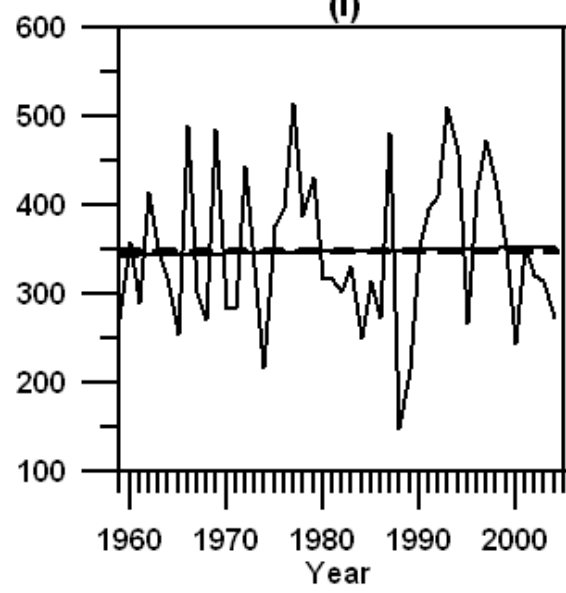

Fig. (2). Year-to-year variation of NEMR and its trend over (a) CAP, (b) Rayalaseema, (c) Tamilnadu, (d) SIK, (e) Kerala sub-divisions and (f) south India as a whole (----- mean and trend lines).

Mann-Whitney rank statistical tests are used in this hind cast study. At the end L-O-O cross validation and RMSE tests are performed for the estimated rainfall from different algorithms to judge them.

\section{RESULTS AND DISCUSSION}

\section{Relationship between SOI and NEMR}

Large scale long term surface pressure sea-saw pattern between Pacific and Indian Oceans region of the tropics is referred as SO. When sea surface pressure is high in Tahiti, it tends to be low in the Darwin and the related index is known as SOI and Fig. (3) shows the correlation between SOI and NEMR for 20-year periods starting at the indicated date. The relationship is first positively correlated between 1880 and 1910 but from 1959 onwards it is negatively correlated. This investigation has not been able to shed any light on the reasons for this reversal, which might be due to factors such as long term changes in global sea surface temperature, so the focus of the remaining activity is to evaluate the skill of statistical forecasts based of the period of negative correlation between SOI and NEMR observed since 1959. It 
is observed that consistency of inverse relationship with NEMR exists for the period 1959-2004. Fig. (4a) shows year-to-year variations of NEMR and SOI (AM) and there is an inverse relationship between them. To quantify the above relationship, the synoptic correlation coefficient is evaluated and it is -0.56 , which is significant at $0.1 \%$ level (Fig. 4b). Significant correlation coefficient between them has recommended an algorithm $\left(\mathrm{R}_{\mathrm{SI}}=-2.56 * \mathrm{SOI}+339.9\right)$ for predicting rainfall, which is tested for six years (1999-2004) and presented in Table 1. Above relationship is true in 32years out of the 46-years (1959-2004). This clearly indicates that the negative (positive) phase of SOI enhances (suppresses) the NEMR. For example in the year 1987 the value of SOI is -46 , when rainfall is $482 \mathrm{~mm}$, while in the year 1989 the value of SOI is 35.7, when rainfall is $214 \mathrm{~mm}$. Further, consistency of the relationship (1959-2004) is tested by 20 -year sliding window test (Fig. 5). All the samples maintained consistent relationship with correlation coefficients exceeding 0.5 , which is significant at $0.1 \%$ level.
Next, Fig. (4a) depicts extreme rainfall events in relation to extreme SOI; there are 15-years with extreme negative SOI, which are less than or equal to mean minus 0.5 standard deviation (SD) and 18-years with extreme positive values, which are greater than or equal to mean plus 0.5 SD are identified and presented (Table 1). The Mann-Whitney rank statistical test is performed for the rainfall associated with the extreme positive and extreme negative SOI events during the above 33 -years. The statistic value is 3.3 (significance at $0.1 \%$ level), which confirms above said inverse relationship in 18 episodes (54\%) out of 33 extreme events. Thus south India received an average amount of $417 \mathrm{~mm}$ rainfall $(19 \%$ excess) during negative SOI events, while an average amount of $288 \mathrm{~mm}$ rainfall ( $9 \%$ deficit) during positive SOI events. This indicates a shift towards wetter (drought) conditions in relation to extreme negative (positive) SOI by higher (lower) frequency of rain-bearing systems (Table 2). Thus the SOI is a potential predictor to evaluate algorithm for NEMR over south India.

Table 1. Actual rainfall (AR), estimated rainfall (ER) and error (E) in cm for three algorithms.

\begin{tabular}{|c|c|c|c|c|c|c|c|}
\hline \multirow{2}{*}{ Year } & \multirow{2}{*}{ Actual Rainfall } & \multicolumn{2}{|c|}{ Algorithm -I } & \multicolumn{2}{|c|}{ Algorithm -II } & \multicolumn{2}{|c|}{ LRF } \\
\hline & & ER & $\mathbf{E}$ & $\mathbf{E R}$ & $\mathbf{E}$ & ER & $\mathbf{E}$ \\
\hline 1999 & 35.1 & 28.9 & 6.2 & 29.2 & 5.9 & 45.5 & -10.4 \\
\hline 2000 & 24.3 & 28.7 & -4.4 & 29.2 & -4.9 & 45.6 & -21.3 \\
\hline 2001 & 35.5 & 36.2 & -0.7 & 31.7 & 3.8 & 35.6 & -0.10 \\
\hline 2002 & 32.1 & 38.6 & -6.5 & 31.3 & 0.8 & 33.5 & -1.40 \\
\hline 2003 & 31.5 & 37.2 & -5.7 & 34.5 & -3.0 & 31.9 & -0.40 \\
\hline 2004 & 27.6 & 34.5 & -6.9 & 35.9 & -8.3 & 33.3 & -5.70 \\
\hline
\end{tabular}

Algorithm -1: Simple linear equation with SOI; Algorithm -II: Simple linear equation with NAO; LRF: Long range forecast equation.

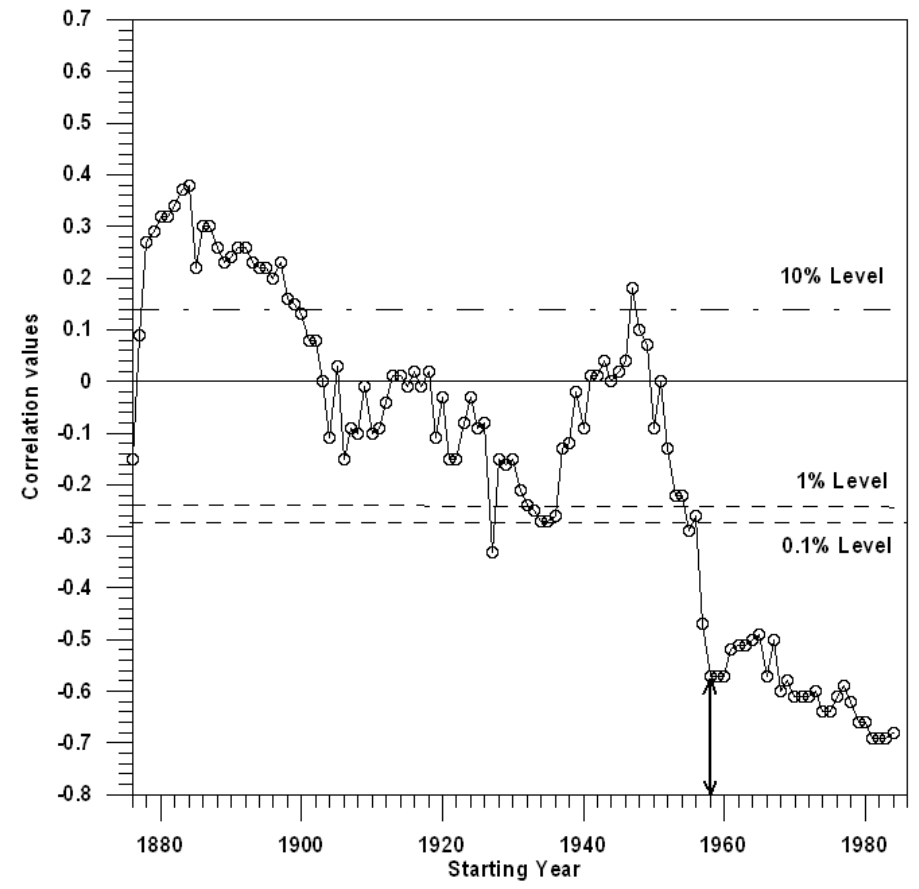

Fig. (3). 20-year sliding correlation coefficients between SOI (AM) and NEMR for the study period, 1876-2004 over south India. 


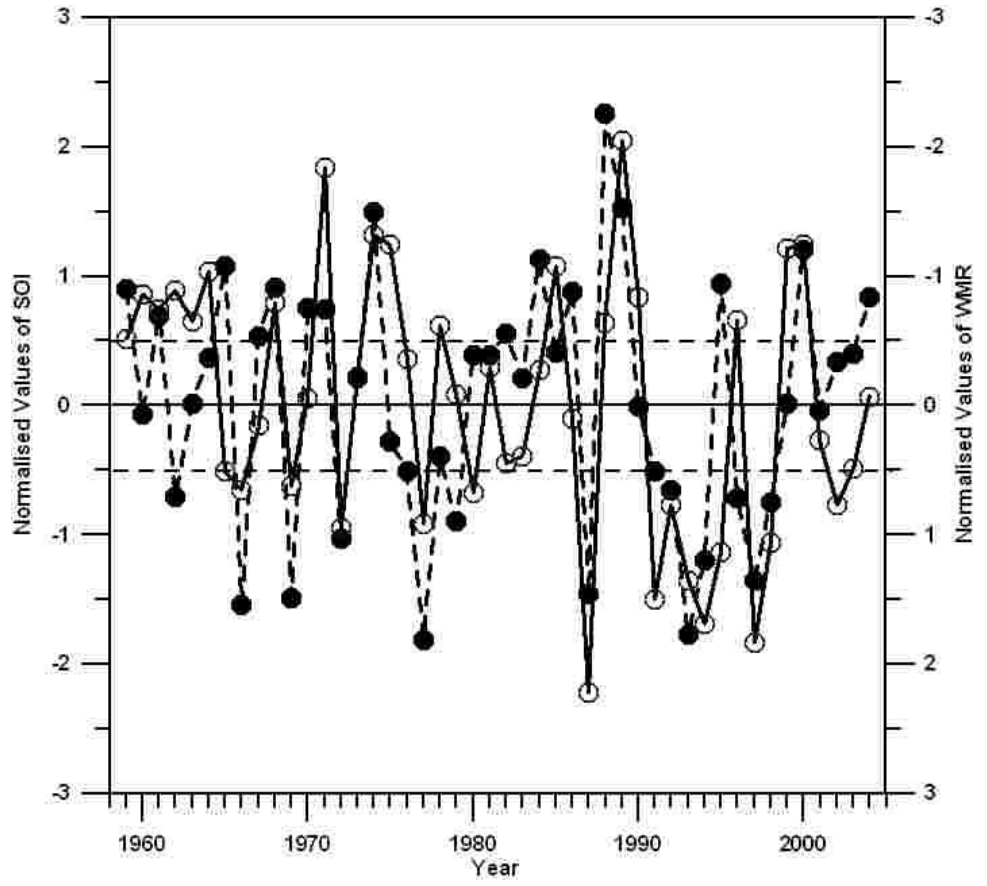

Fig. (4a). Year-to-year variations of SOI in April and May (continuous line) with NEMR (dotted line) over south India for the period 19592004.

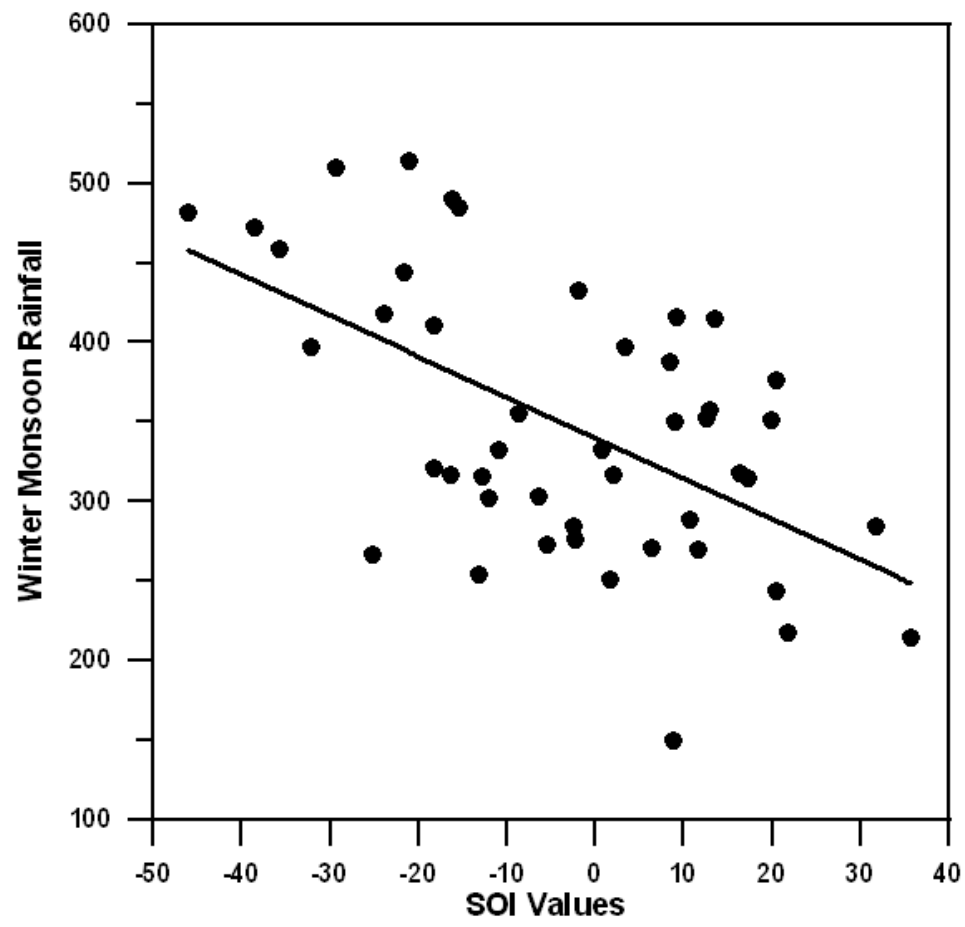

Fig. (4b). Scatter plot of SOI vs. NEMR for the period 1959-2004.

\section{Influence of NAO on NEMR}

The NAO exerts a strong influence on global climate variability and there is an evidence of longer term trends. It is related to the shorter term shift between zonal and meridional circulation types that occurs on day-to-day timescale. Year-to-year variations of NEMR and NAO (JF) are related for the study period in Fig. (6) and the relationship between them is negative, which demonstrates that there is an excess of rainfall over south India during negative NAO index period. In the year 1977 the value of NAO is -2.7 , when rainfall is $514 \mathrm{~mm}$ and similarly in the year 2000 the value of NAO is 3.1, when rainfall is $243 \mathrm{~mm}$. The strength of above relationship is quantified and it amounts to -0.35 , which is significant at the $5 \%$ level and the algorithm formulated to predict rainfall is $\mathrm{R}_{\mathrm{SI}}=-19.7 *$ $\mathrm{NAO}+353.1$, which is tested (Table 1). Further the consistency of above relationship is tested by 20 -year sliding window test (Fig. 5). Next on examining the extreme cases 
Table 2. Extreme values of SOI (AM) and NEMR over south India along with cyclonic systems.

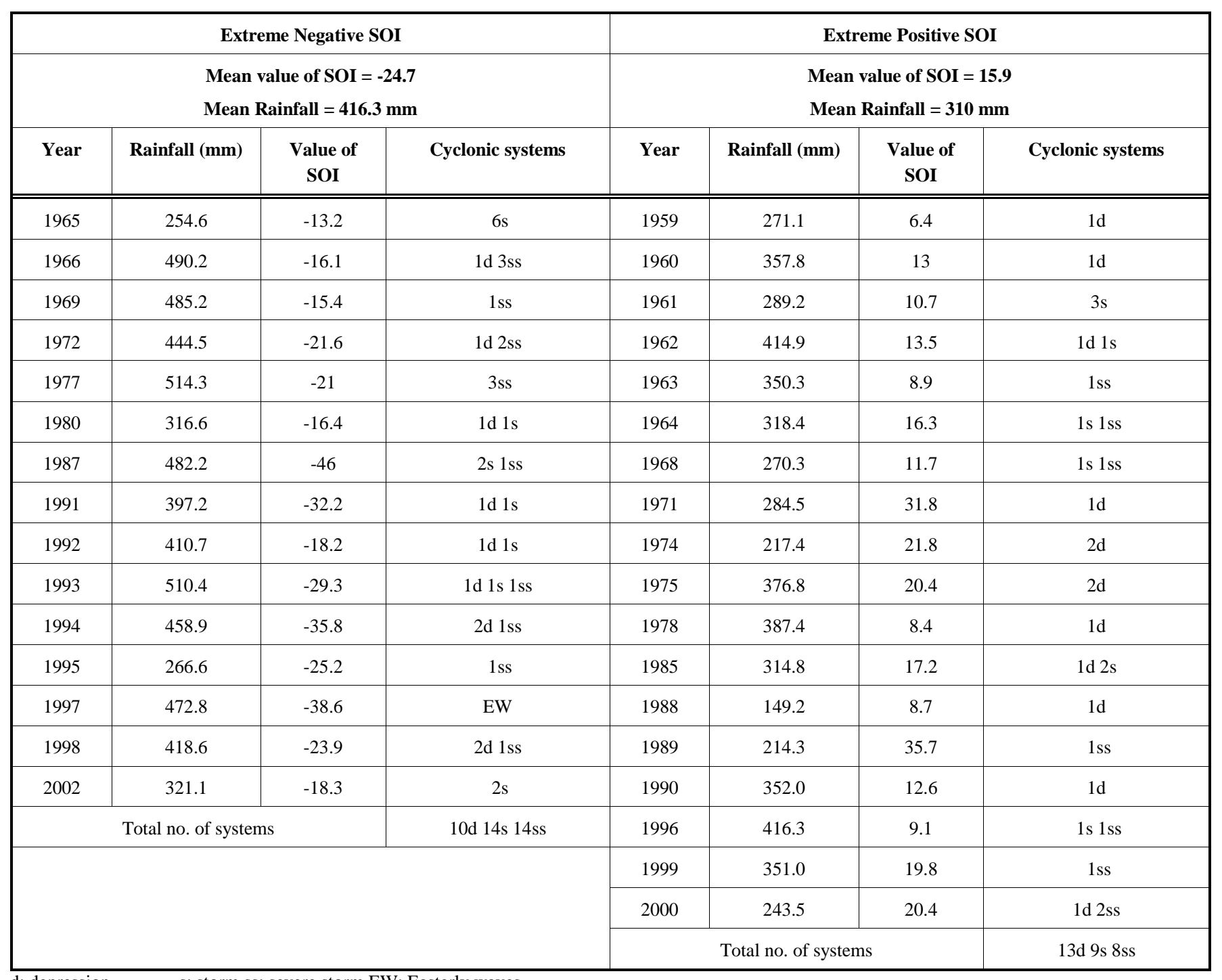

of rainfall events it is found that there are 14 extreme negative and 18 extreme positive NAO episodes exist during the study period (Fig. 6) and they are presented in Table $\mathbf{3}$. By applying Mann-Whitney rank statistical test for the rainfall associated with extreme negative and positive episodes of NAO for the above 32 episodes, the MannWhitney statistic value is 1.2 , which is significant. Thus south India receives $383 \mathrm{~mm}$ (8\% excess) rainfall in negative episodes and $341 \mathrm{~mm}$ (9\% deficit) rainfall in positive cases. Hence this predictor is also useful to take as one of the forcing factors for the assessment of rainfall over south India. By and large higher frequencies of tropical cyclones are observed during extreme negative cases of NAO and vice-versa.

Though separate algorithms are formulated using predictors SOI and NAO for predicting rainfall, now the authors wish to improve above equations using the combined effect of above two predictors.

\section{Long Range Forecast Equation for Predicting NEMR}

In this hind cast study authors have identified two potential predictors namely SOI and NAO from Pacific, Atlantic and Indian oceans to predict seasonal rainfall and the inter correlation between them is insignificant (0.11); the MCC among them is 0.66 , which is significant at the $0.1 \%$ level with a coefficient of determination (COD) of $44 \%$. Above significant MCC suggests an algorithm to predict seasonal rainfall over south India $\left(\mathrm{R}_{\mathrm{SI}}\right.$ in $\left.\mathrm{mm}\right)$ as follows:

$\mathrm{R}_{\mathrm{SI}}=345.6-2.6 * \mathrm{SOI}{ }_{(\mathrm{AM})}-18.8 * \mathrm{NAO}_{(\mathrm{JF})}------1$

where $\mathrm{R}_{\mathrm{SI}}$ is the rainfall over south India

The above equation is tested over the period 1999-2004 and presented in Table $\mathbf{I}$ along with the actual rainfall (AR) and predicted rainfall (PR). Though the model estimates are moderately excess, rainfall is close to the actual for the years 2001 through 2003. As the number of samples tested in this study are six only, the L-O-O cross validation test is applied 




Fig. (5). 20-year sliding correlation coefficients between SOI (continuous line), NAO (dotted line) and NEMR for the study period 19592004 over south India.

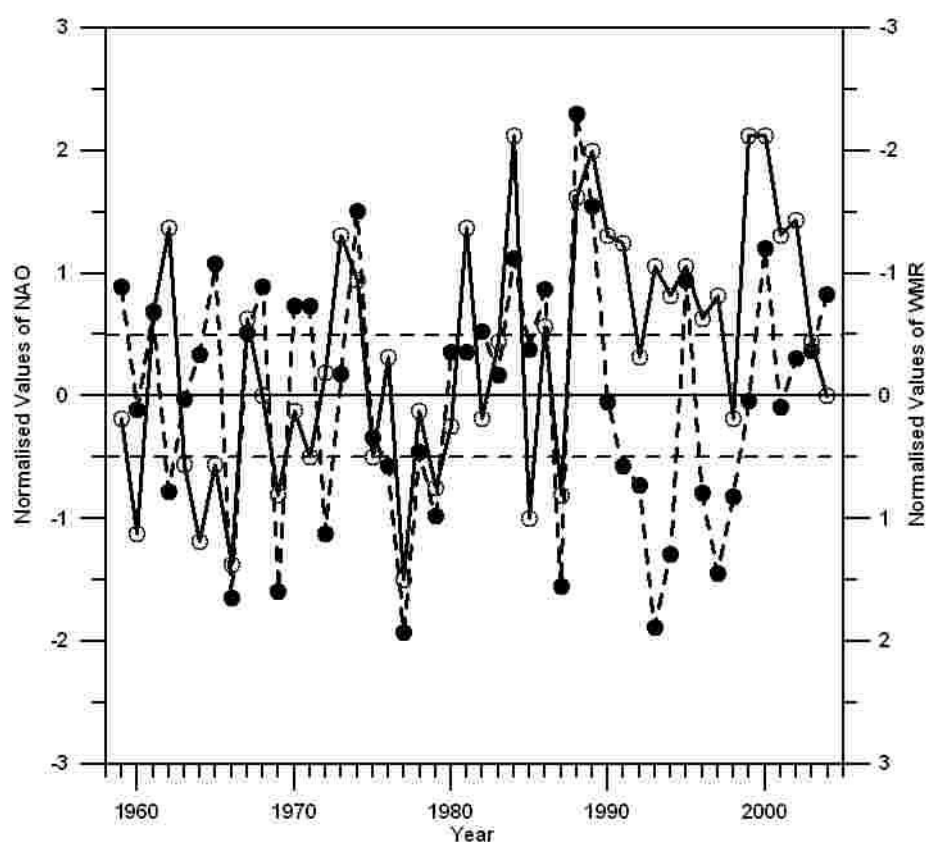

Fig. (6). Year-to-year variations of NAO in January and February (continuous line) with NEMR (dotted line) over south India for the period 1959-2004.

and it is significant at $5 \%$ level. The Root Mean Square Error (RMSE) for this test period is also calculated, which is 89.8 $\mathrm{mm}$.

\section{Observational Evidence for the Influence of SOI on Hadley Cell in November}

The NCEP/NCAR reanalysis wind data is used for observational study of Hadley cell in extreme years of SOI and the anomaly circulation changes are prepared from mean. The potency of SOI (AM) on northeast monsoon circulation in terms of strength and extent of tropical Hadley cell across India and neighborhood is examined. Vertical cross sections of Hadley cell along $80^{\circ} \mathrm{E}$ during extreme negative (1987) and extreme positive (1989) SOI are prepared (Figs. (7a, b)) by using mean November meridional. Though northerlies exist in both years, there is a difference in strength. A core of maximum northerlies $\left(4.8 \mathrm{~ms}^{-1}\right)$ is present around $900 \mathrm{hPa}$ in the equatorial region and another core at $600 \mathrm{hPa}$ at the latitudes, $20^{\circ}-25^{\circ} \mathrm{N}$ in 1987 , while they are 
Table 3. Extreme values of NAO (JF) and NEMR over south India along with cyclonic systems.

\begin{tabular}{|c|c|c|c|c|c|c|c|}
\hline \multicolumn{4}{|c|}{ Extreme Negative NAO } & \multicolumn{4}{|c|}{ Extreme Positive NAO } \\
\hline \multirow{2}{*}{\multicolumn{4}{|c|}{$\begin{array}{l}\text { Mean value of NAO = -1.6 } \\
\text { Mean Rainfall }=383.2 \mathrm{~mm}\end{array}$}} & \multirow{2}{*}{\multicolumn{4}{|c|}{$\begin{array}{l}\text { Mean value of NAO }=1.8 \\
\text { Mean Rainfall }=335 \mathrm{~mm}\end{array}$}} \\
\hline & & & & & & & \\
\hline Year & Rainfall (mm) & Value of NAO & Cyclonic systems & Year & Rainfall (mm) & Value of NAO & Cyclonic systems \\
\hline 1960 & 357.8 & -2.1 & $1 d$ & 1962 & 414.9 & 1.9 & $1 \mathrm{~d} 1 \mathrm{~s}$ \\
\hline 1963 & 350.4 & -1.2 & $1 \mathrm{ss}$ & 1973 & 332.4 & 1.8 & $1 d$ \\
\hline 1964 & 318.4 & -2.2 & $1 \mathrm{~s} 1 \mathrm{ss}$ & 1974 & 217.4 & 1.2 & $2 d$ \\
\hline 1965 & 254.6 & -1.2 & $6 s$ & 1981 & 317.2 & 1.9 & $1 \mathrm{~s} 2 \mathrm{ss}$ \\
\hline 1966 & 490.2 & -2.5 & $1 \mathrm{~d} 3 \mathrm{ss}$ & 1984 & 250.7 & 3.1 & $1 \mathrm{~s}$ \\
\hline 1969 & 485.2 & -1.6 & $1 \mathrm{ss}$ & 1986 & 272.7 & 0.6 & $1 \mathrm{~s}$ \\
\hline 1970 & 284.2 & -0.5 & $1 d$ & 1988 & 149.2 & 2.3 & $1 \mathrm{~d}$ \\
\hline 1971 & 284.5 & -1.1 & $1 d$ & 1989 & 214.3 & 2.9 & $1 \mathrm{ss}$ \\
\hline 1975 & 376.8 & -1.1 & $2 d$ & 1990 & 352.0 & 1.8 & $1 \mathrm{~d}$ \\
\hline 1977 & 514.3 & -2.7 & $3 \mathrm{ss}$ & 1991 & 397.2 & 1.7 & $1 \mathrm{~d} 1 \mathrm{~s}$ \\
\hline 1979 & 432.4 & -1.5 & $3 \mathrm{~s}$ & 1993 & 510.4 & 1.4 & $1 \mathrm{~d} 1 \mathrm{~s} 1 \mathrm{ss}$ \\
\hline 1985 & 314.8 & -1.9 & $1 \mathrm{~d} 2 \mathrm{~s}$ & 1994 & 458.9 & 1.0 & $2 \mathrm{~d} 1 \mathrm{ss}$ \\
\hline 1987 & 482.2 & -1.6 & $2 \mathrm{~s} 1 \mathrm{ss}$ & 1996 & 416.3 & 0.7 & $1 \mathrm{~s} 1 \mathrm{ss}$ \\
\hline 1998 & 418.6 & -0.6 & $2 \mathrm{~d} 1 \mathrm{ss}$ & 1997 & 472.8 & 1.0 & EW \\
\hline \multicolumn{3}{|c|}{ Total no. of systems } & $9 \mathrm{~d} 14 \mathrm{~s} 11 \mathrm{ss}$ & 1999 & 351.0 & 3.1 & $1 \mathrm{ss}$ \\
\hline & & & & 2000 & 243.5 & 3.1 & $1 \mathrm{~d} 2 \mathrm{ss}$ \\
\hline & & & & 2001 & 355.3 & 1.8 & $2 \mathrm{~s}$ \\
\hline & & & & 2002 & 321.1 & 2.0 & $2 \mathrm{~s}$ \\
\hline & & & & \multicolumn{3}{|c|}{ Total no. of systems } & $11 \mathrm{~d} 11 \mathrm{~s} 8 \mathrm{ss}$ \\
\hline
\end{tabular}

weak in 1989. Secondly to further substantiate the strength of northerlies anomaly (vertical cross section), Hadley cell is also prepared by subtracting extreme weak/strong event from 46-years (1959-2004) mean of November; Fig. (7 c \& d) shows that northerlies prevail up to the middle troposphere in good monsoon year (1987) where as weak southerly component appeared in 1989. Later the horizontal extent of meridional cell at $1000 \mathrm{hPa}$ is also examined in above two contrasting years (Fig. (8 a \& b)). During November 1987 the horizontal extent of Hadley cell is more over northeast monsoon region and the Bay of Bengal with a maximum speed of $4.2 \mathrm{~ms}^{-1}$ where as the above cell is weak and over the eastern Bay of Bengal only in 1989. Next the anomaly meridional winds of northerlies during the above two extreme years at $1000 \mathrm{hPa}$ in November are calculated and presented. In November 1987 the anomaly winds at 1000 $\mathrm{hPa}$ are northerlies over the Bay of Bengal with a core of maximum $1.5 \mathrm{~ms}^{-1}$ in the region $8^{\circ}-10^{\circ} \mathrm{N}$ and $76^{\circ}-83^{\circ} \mathrm{E}$ (Fig. 8c), where as in November 1989, the winds are opposite to those of 1987. The anomaly southerlies are present over major part of Bay of Bengal with a core of maximum $2.1 \mathrm{~ms}^{-1}$ in the region $4^{\circ}-12^{\circ} \mathrm{N}$ and $85^{\circ}-93^{\circ} \mathrm{E}$
(Fig. 8d). Above synoptic study clearly demonstrates that when SOI (AM) is strong (weak), the strength and extent of tropical Hadley cell over south India and Bay of Bengal is greater than normal and this in turn cause good (poor) NEMR.

\section{SUMMARY AND CONCLUSIONS}

The signature of mean monthly global pressure oscillations namely SOI (AM) and NAO (JF) show some skills for predicting NEMR over south India, which is linked with the frequency and intensity of weather disturbances from the Bay of Bengal.

Though the algorithm slightly over estimates it is reasonably good for the seasonal prediction of rainfall.

Observational evidence in terms of modulation of tropical Hadley circulations by the variations of mean monthly pressure oscillations is also demonstrated as a part of full proof of inverse relationships detected in this study. 
(a)

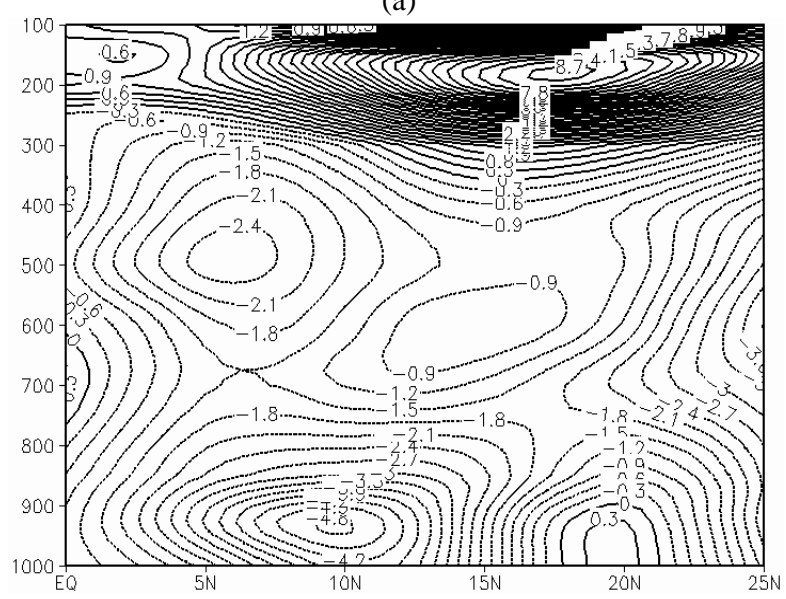

(b)



Fig. (7). (a \& b). Vertical cross section of Hadley Cell along 800E over northeast monsoon region during (a) extreme negative SOI (1987) and (b) extreme positive SOI (1989) in November.

(c)



(d)

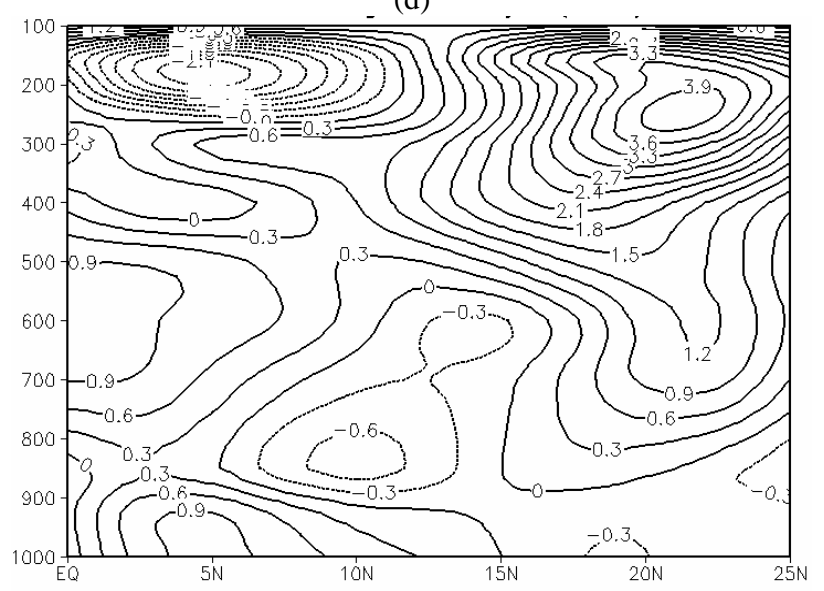

Fig. (7). (c \& d). Anomaly Vertical cross section of Hadley Cell along 800E over northeast monsoon region during (c) extreme negative SOI (1987) and (d) extreme positive SOI (1989) in November.
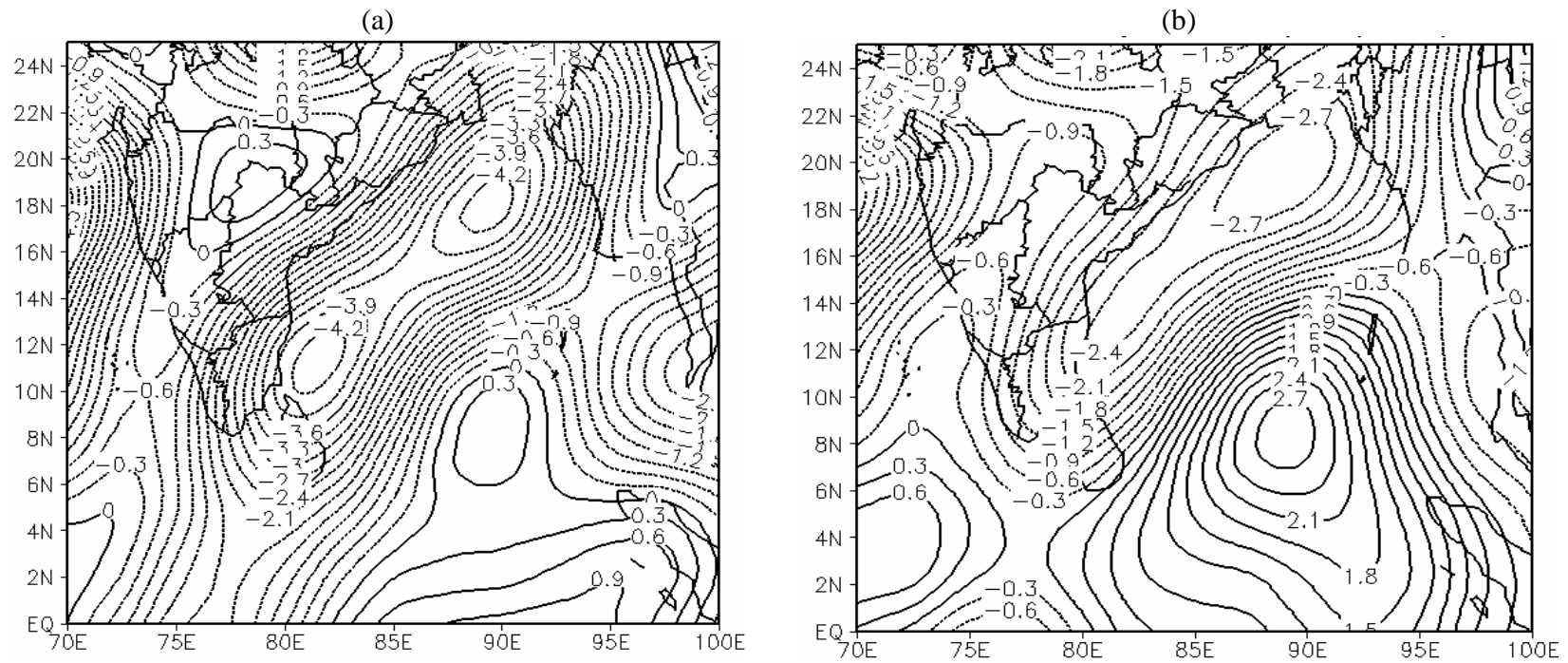

Fig. (8). (a \& b). Horizontal structure and strength of Hadley cell over northeast monsoon region during (a) Extreme negative SOI (1987) and (b) Extreme positive SOI (1989) in November at $1000 \mathrm{hPa}$. 

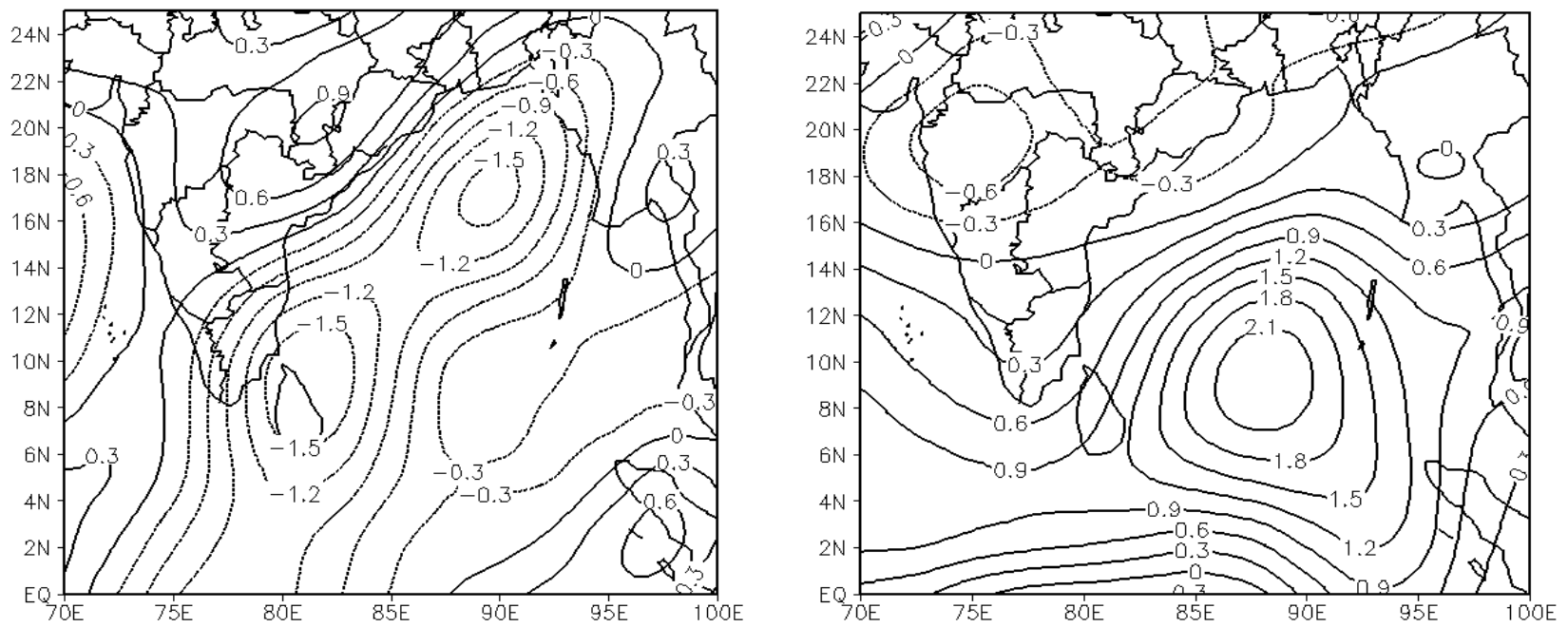

Fig. (8). (c \& d). Anomaly mean meridional winds over northeast monsoon region during (c) extreme negative SOI (1987) and (d) extreme positive SOI (1989) in November at $1000 \mathrm{hPa}$.

Thus Indian northeast monsoon is due to a series of feedback mechanisms, where in global equatorial pressure oscillation indices namely SOI and NAO are two such parameters to control monsoon over south India.

\section{CONFLICT OF INTEREST}

The author confirms that this article content has no conflict of interest.

\section{ACKNOWLEDGEMENT}

The author is thankful to the Council of Scientific and Industrial Research, New Delhi for their financial support through SRA scheme (No.13(8607-A) 2013- Pool) and also thankful to the NCEP/NCAR, IITM and Australian Bureau of Meteorology for providing data.

\section{REFERENCE}

[1] Blanford HF. On the connexion of the Himalayan snowfall with dry winds and seasons of drought in India. Pro R Soc Lond 1884; 37: 3-22.

[2] Das PK. Monsoons. WMO No.613; 1986.

[3] Iyer D. Forecasting the northeast monsoon rainfall of south Madras. Scientific Note No. 98, Ind Met Depart 1946; 147-54.

[4] Rao KPR, Jagannathan P. A study of the northeast monsoon rainfall of Tamilnadu. Ind J Met Geophys 1953; 4: 22-43.

[5] Subbaramayya I. The northeast monsoon and the causes of the winter rains of southeast India. Met Mag 1976; 105: 153-9.

[6] Kumar B OSRU, Rao RS, Krishna MK. Study of intra annual and intra seasonal variations of Indian summer monsoon during ARMEX period. Orally presented in the National Workshop on Arabian Sea Monsoon Experiment, during 19-22 April, 2006 at National Institute of Oceanography, Goa, India 2006.

[7] Mooley DA. Variation of summer monsoon rainfall over India in El Niño, Mausam 1997; 48: 413-20.

[8] Parthasarathy B, Panth GB. Seasonal relationships between Indian summer rainfall and the southern oscillation. J Climate 1985; 5: 369-78.

[9] Rasmusson EM. Carpenter TH. The relationship between eastern equatorial Pacific sea surface temperatures and rainfall over India and Sri Lanka. Mon Wea Rev 1983; 111: 517-28.
[10] Ropelewski CF, Halpert MS. Precipitation patterns associated with the high index phase of the southern oscillation. J Clim 1989; 2: 268-84.

[11] Shukla J, Paolino DA. The southern oscillation and long range forecasting of the summer monsoon rainfall over India. Mon Wea Rev 1983; 111: 1830-7.

[12] Sikka DR. Some aspects of large scale fluctuations of summer monsoon rainfall over India in relation to fluctuations in the planetary and regional scale circulation parameters. Proc Ind Acad Sci (Earth and Planetary Sciences), 1980; 89: 179-95.

[13] Sridharan S, Muthusamy A. Northeast monsoon rainfall in relation to El Niño, QBO and Atlantic hurricane frequency. Vayu Mandal 1990; 20: 108-11.

[14] Kumar KK, Rajagopalan B, Cane MA. On the weakening relationship between the Indian monsoon and the ENSO. Science 1999; 284: 2156-9.

[15] Kumar B OSRU, Naidu CV, Rao RS. Prediction of southern Indian winter monsoon rainfall from September local upper-air temperatures. Met Appl 2004(a); 11: 189-99.

[16] Kumar B OSRU, Naidu CV, Rao RS. Influence of Southern Oscillation and SSTs over Nino-3.4 region on the winter monsoon rainfall over Coastal Andhra Pradesh. Proc Ind Aca Sci 2004; 113: 313-19.

[17] Bhanu Kumar OSRU. Impact of ENSO on Winter Monsoon Rainfall over south India. Geophys Res Abstracts 2005; 7: 03869.

[18] Bhanu Kumar OSRU, Muni Krishna K, Ramalingeswara Rao S. Simulation of environmental heavy rainfall episodes during June and July 2006 - a case study. Can J Pure Appl Sci 2008; 2: 211-20.

[19] De US, Mukhopadhyay RK. The effect of ENSO/Anti ENSO on northeast monsoon rainfall. Mausam 1999; 50: 343-54.

[20] Janyanti N, Govindhachari S. El Nino and northeast monsoon rainfall over Tamilnadu. Mausam 1999; 50: 217-8.

[21] Rao NG. Variations of the SO relationship with summer and winter monsoon rainfall over India: 1872-1993. J Climate 1999; 12: 348695.

[22] Singh GP, Chattopadhyay J. Influence of some circulation anomalies on Indian northeast monsoon rainfall. Mausam 1998; 49: 443-8.

[23] Rajagopalan B, Kushnir Y, Tourre Y. Observed decadal midlatitude and tropical Atlantic climate variability. Geophys Res. Lett. 1998; 25: 3967-70.

[24] Robertson AW, Mechoso CR, Kim YJ. The influence of Atlantic sea surface temperature anomalies on the North Atlantic oscillation, J Climate 2000; 13: 122-38.

[25] Sutton RT, Norton WA, Jewson SP. The North Atlantic oscillation. What role for the ocean? Atmos Sci Lett 2001; 1, 89$100,10.1006 /$ asle. 2000.0018 
[26] Venzke S, Allen MR, Sutton RT, Rowell DP. The atmospheric response over the North Atlantic to decadal changes in sea surface temperatures. J Climate 1999; 12: 2562-84.
[27] Xie S-P, Tanimoto Y. A pan-Atlantic decadal climate oscillation. Geophys Res Lett 1998; 25: 2185-8.

[28] Kalnay E, Kanamitsu M, Kistler R, et al. The NCEP/NCAR 40year reanalysis project. Bull Am Met Soc 1996; 77: 437-71.

Received: July 23, 2014

(C) S. R. Rao; Licensee Bentham Open.

This is an open access article licensed under the terms of the Creative Commons Attribution Non-Commercial License (http://creativecommons.org/licenses/by-nc/3.0/) which permits unrestricted, non-commercial use, distribution and reproduction in any medium, provided the work is properly cited. 